\title{
NEW RULES ON BRAZIL / US COOPERATION, BETWEEN THE FRUSTRATED PRODUCTION OF RENEWABLE FUELS AND THE CHALLENGES OF THE BIO-ECONOMY 1 (2006-2018)
}

NOVAS REGRAS PARA A COOPERAÇÃO BRASIL/ EUA, ENTRE A PRODUÇÃO FRUSTRADA DE COMBUSTÍVEIS RENOVÁVEIS E OS DESAFIOS DA BIOECONOMIA (2006-2018)

\section{NUEVAS REGLAS PARA LA COOPERACIÓN BRASIL/ EUA, ENTRE LA PRODUCCIÓN FRUSTRADA DE COMBUSTIBLESRENOVABLES YLOS DESAFÍOSDELABIOECONOMÍA (2006-2018)}

Licença CC BY:

Artigo distribuído sob os termos Creative Commons, permite uso e distribuição irrestrita em qualquer meio desde que o autor credite a fonte original.

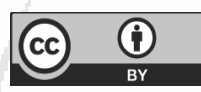

\section{Antonio Yang ${ }^{2}$}

\section{Wilson Almeida ${ }^{3}$}

Abstract: The industry of the 21st Century will be totally different from the one we experienced in the 19th and 20th centuries. It will be technology-intensive and energy-wise clean. The industry of the 21 st century should be biodegradable and sustainable. Instead of transforming only products and raw materials it must transform the human beings. Brazilian agriculture with its technological advances and sophisticated production may be an important partner of the United States to create a new biological industry for the 21st Century. Brazil is the world's leading producer of cotton, orange juice, chicken, beef, sugar, ethanol, biodiesel, soy, corn, among others. Brazil has the latest technology to genetically modify plants and animals. The United States is the world's largest producer of many of the state-of-the-art technology products. Cooperation between the two countries in terms of genetic improvement of plants and animals has lasted for more than 40 years. Now, the next challenge is to invent a new industry and a new economy that can face the challenges ahead. These are some of the key gates to the bioeconomy.

1 I thank Georgetown University for hosting this research, to CNPq, Brazil and, the Catholic University of Brasilia for financial support.

2 Professor and researcher at the Chihlee University of Technology, Taipei ROC. Ph.D. in Cooperation with ROC and Latin America.

3 Professor of International Law and International Relations at the Catholic University of Brasilia; Visiting Researcher at Georgetown University, Washington, DC, in 2018. Avocational Lecturer at the Steinbeis University of Berlin, since 2015 and Advisor to the Chihlee University of Technology, Taipei. 
Keywords: rules; cooperation; production of renewable fuels; bio-economy.

Resumo: A indústria do século XXI será totalmente diferente daquela que vivenciamos nos séculos $X I X$ e XX. Será uma indústria intensiva em tecnologias e de energia limpa e inteligente. A indústria do século XXI deveria ser biodegradável e sustentável. Em vez de transformar apenas produtos e matérias-primas, ela deve transformar o próprio homem. A agricultura brasileira, com seus avanços tecnológicos e produção sofisticada, pode ser uma importante parceira dos Estados Unidos para criar uma nova indústria biológica para o século XXI. O Brasil é líder na produção de algodão, suco de laranja, frango, carne bovina, açúcar, etanol, biodiesel, soja, milho, entre outros. O Brasil detém a mais recente tecnologia de plantas e animais geneticamente modificados. Os Estados Unidos são o maior produtor de muitos dos mais evoluídos produtos tecnológicos. A cooperação entre os dois países em termos de melhorias genéticas de plantas de animais já ocorre há mais de 40 anos. Agora, o próximo desafio é inventar uma nova indústria e uma nova economia que possam fazer frente aos desafios futuros. Esses são alguns dos portais essenciais para a bioeconomia.

Palavras-chave: regras; cooperação; produção de combustíveis renováveis; bioeconomia.

Resumen: La indústria del siglo $X X I$ será totalmente diferente de aquella que vivenciamos en los siglos XIX y XX. Será una industria intensa en tecnologías y de energía limpia e inteligente. La industria del siglo XXI debería ser biodegradable y sostenible. Al invés de transformar apenas productos y materias primas, ella debe transformar el propio hombre. La agricultura brasileña, con sus avances tecnológicos y producción sofisticada, puede ser una importante compañera de los Estados Unidos para crear una nueva industria biológica para el siglo XXI. El Brasil es líder en la producción de algodón, jugo de naranja, pollo, carne bovina, azúcar, etanol, biodiesel, soja, maíz, entre otros. El Brasil tiene la última tecnología de plantas y animales genéticamente modificados. Los Estados Unidos son el mayor productor de muchos de los más evoluídos productos tecnológicos. La cooperación entre los dos países en términos de mejorías genéticas de plantas de animales ya ocurre ha más de 40 años. Ahora, el próximo desafío es inventar una nueva industria y una nueva economía que puedan hacer frente a los desafíos futuros. Estos son algunos de los portales esenciales para la bioeconomía.

Palabras-clave: reglas; cooperación; producción de combustibles renovables; bioeconomía.

INTRODUCTION

Former President Barak Obama in his speech on October 5th, 2017 in Sao Paulo, affirmed the responsibility of the United States and Brazil, as the two largest democracies in the hemisphere, to address the main problems facing the planet. He spoke of the important technological changes and cooperation, coincidentally the subject of this study. 
I believe that the two largest democracies in the hemisphere and two of the world's largest economies, like us, have the unique opportunity and responsibility to reach this unceasing pace of globalization and technological change, face challenges such as terrorism, economic inequality, future of the region but also the whole world. ${ }^{4}$

The world that begins to be unveiled in the second decade of the XXI Century has some visible contours, although it is difficult to see it in its entirety. That is why there are not many regularities observed in recent times. One of the contours that can be seen and described is the new global patterns of cooperation that can be seen in global treaties a human rights, environmental protection to mitigate a very polluted past and a future still uncertain, actions of nongovernmental organizations and even international standards to regulate trade practices, cooperation standards on intellectual property, regulations to establish procedures to combat international crimes such as drug trafficking, arms and people.

One of the most important and challenging topics of cooperation is the limited and scarce consumption of energy and natural resources on earth. This research tries to understand the cooperation between the United States and Brazil in the production of renewable energies, like biofuels, originated from plants, for the replacement of part of the consumption of fossil fuels, reducing the emissions of Greenhouse Gases.

\section{THE ETHANOL DIPLOMACY BETWEEN PROMISE AND STRATEGY}

In 2009, I published an article at Universal - Georgetown University, which analyzed the two largest ethanol producers in the world, which differ basically by the raw material used. One uses sugar cane, Brazil, and another corn, the United States. Ethanol has some advantages in its use as fuel: it reduces $\mathrm{CO} 2$ emissions when added to gasoline and reduces the need for fossil fuel consumption. These were the two and most important promises of the project that was called Ethanol

4 OBAMA, Barak. Discurso no Fórum Cidadão Global. Valor Econômico, retrieved from http://www.valor.com.br// brasil/5147036/leia-integra-da-palestra-de-barack-obama-no-forum-cidadao-global, on 06/10/2017. 
Diplomacy. The third promise of this project was to increase cooperation between Latin America, the Caribbean, and part of Africa to produce large quantities of ethanol that would be exported to the United States and other major oil consumers. $^{5}$

The wishes of the governments of Brazil and the US at that time were manifested in a Memorandum of Understanding, MOU, which they interpreted as being important.

On March 9, Secretary of State Condoleezza Rice and Brazilian Foreign Minister Celso Amorim signed a memorandum of understanding to advance cooperation on biofuels. The agreement highlights the importance of biofuels as a transformative force in the region to diversify energy supplies, bolster economic prosperity, advance sustainable development, and protect the environment.

The United States and Brazil already are working through existing mechanisms such as the U.S.-Brazil Commercial Dialogue launched in 2006, the U.S.-Brazil Consultative Committee on Agriculture established in 2003, the 1999 U.S.-Brazil Memorandum of Understanding on Energy, the U.S.-Brazil Common Agenda for the Environment established in 1995, and our 1984 Framework Agreement on Science and Technology. ${ }^{6}$

There was an important indicator that the project would be successful because the business community, mainly from the United States, was convinced of the good project opportunities and this was evidenced in the investments made by US companies that bought ethanol plants in Brazil between 2006 and 2010.7

Brazil has one of the best ethanol production technologies in the world and uses the most productive raw material, sugarcane. According to the study cited in Almeida (2009), Brazil should produce much more ethanol, taking advantage of areas of degraded pastures and create conditions for other countries in the Caribbean, South America, and Africa also to produce using the technology and expertise of Brazil, with the objective of supplying consumption in the

$5 \quad$ ALMEIDA, Wilson J. B. Ethanol Diplomacy: Brazil and the U.S. in Search of Renewable Energy. Revista de Globalizacion, Competitividad y Gobernabilidad, v. 3, p. 114-124, 2009.

6 STATE DEPARTMENT. Advancing Cooperation with Brazil on Biofuels. 2006. Retrieved from https://2001-2009. state.gov/r/pa/prs/ps/2007/mar/81589.htm, on 27/09/2017.

7 ALMEIDA, Wilson J. B. Ethanol Diplomacy: Brazil and U.S. in Search of Renewable Energy. Revista de Globalizacion, Competitividad y Gobernabilidad, v. 3, p. 114-124, 2009. 
United States, which in turn would exchange part of the ethanol consumption of corn that is not very productive, by importing sugarcane ethanol from all these regions. This is part of a win-win game where greenhouse gas emissions are reduced and at the same time jobs are created in emerging countries, reducing poverty in the world.

The time passed and the great project did not continue. The investments of the American companies stopped in the years 2011-12 and some companies were sold as is the case of Brazilian Renewable Energy Ltda. (BRENCO), that announced the construction of several plants (more than 20) until 2020 to produce more than $20 \%$ of all Brazilian ethanol. ${ }^{8}$

The curiosity of research can be materialized in some questions, why did a project with great possibilities of economic, social and even environmental viability not evolve? What happened to large business groups advised by risk analysts to make a mistake in their calculations of investment opportunities? With the signing of the Paris Agreement, an opportunity to incentivize the ethanol production sector to reduce $\mathrm{CO} 2$ emissions, are there prospects for the future?

The United States is one of the largest energy consumers on the planet. Its consumption depends on fossil energy sources, consequently promoting the devastation of the ozone layer with GHG emissions. Several US administrations have been forced to threaten the rest of the world with their doctrines and corollaries against attempts to stop the flow of oil to themselves and their allies. Dependence on oil was always high on the agenda of US foreign policy and was one of its biggest headaches. ${ }^{9}$

\section{THE US TRAP BETWEEN DEPENDENCY AND SELF-SUFFICIENCY}

When former President Obama came to power, US oil production was 5.1 MMb/d (millions of barrels per day). In the years 2005 to 2007, the US imported around $10 \mathrm{MMb} / \mathrm{d}$ of oil. The prevailing environment between government and

\footnotetext{
8 BLOOMBERG (2017), retrieved from https://www.bloomberg.com/research/stocks/private/snapshot. asp?privcapld=33230078 on 28/09/17. ALMEIDA, Wilson J. B. Ethanol Diplomacy: Brazil and the U.S. in Search of Renewable Energy. Revista de Globalizacion, Competitividad y Gobernabilidad, v. 3, p. 114-124, 2009.

9 ALMEIDA, Wilson J. B. Ethanol Diplomacy: Brazil and the U.S. in Search of Renewable Energy. Revista de Globalizacion, Competitividad y Gobernabilidad, v. 3, p. 114-124, 2009.
} 


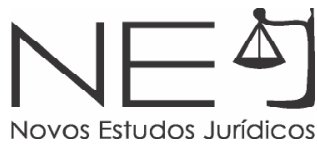

business was a challenge to keep the balance of energy balanced and security guaranteed. The Carter Doctrine was often repeated to warn the "hostile governments" that the US would not tolerate any threat to the disruption of oil flow that would compromise its consumption or the consumption of its allies.

The United States' external dependence on energy was aggravated, and all projections were of intensifying this dependence. The government of President Obama decided to strongly encourage the production of shale derivatives, an abundant raw material in his country.

After major transformations in shale research and exploration over just 8 years, US domestic oil production in 2018 is projected to exceed $9.8 \mathrm{MMb} / \mathrm{d}$. This result is greater than its output in 1970 when the US was still self-sufficient.

The EIA ${ }^{10}$ reports that with more than 9.3 million barrels per day in 2016, US production surpassed Russia's output. EIA projects to 2017 that the United States produces more than Saudi Arabia, the world's largest producer.

EIA forecasts total U.S. crude oil production to average 9.3 million b/d for all of 2017 and 9.8 million b/d in 2018, which would mark the highest annual average production in U.S. history, surpassing the previous record of 9.6 million b/d set in $1970 .{ }^{11}$

The growth of domestic oil production in the US is a result of exploration with the hydraulic fracturing technique to extract deposits of hydrocarbons in deep rocks. This has meant reducing the proportion of imported oil in US consumption from $40 \%$ in recent years to $25 \%$ of the total. It is the lowest level since 1985 . At the peak of dependence, in $2005,60 \%$ of the oil consumed by the United States was imported.

The large-scale exploration of gas and shale oil in the United States transformed all the scenarios on energy production and consumption in the world and led government and companies to better control the main sources of energy consumed in their country.

10 EIA - International Energy outlook 2017. Washington, DC. retrieved from https://www.eia.gov/pressroom/ presentations/mead 91417.pdf on 18/18/2017.

11 EIA - International Energy Outlook 2017. Retrieved from https://www.eia.gov/outlooks/steo/, on 17/09/2017. 
The US shale gas reserve is estimated at 318 trillion cubic feet, according to the Energy Information Administration (EIA, 2014) calculations. It will be sufficient to supply the United States for over 100 years.

The technique is controversial because of the environmental risks it causes, such as the possible contamination of waters from natural sources, the infiltration of chemicals in the soil and even an increase in the occurrence of earthquakes.

Despite all the other factors, this type of drilling and extraction has become more and more frequent given the strategy of energy production and combat dependence that the US had since the 1980s.

The U.S. dry natural gas production is forecast to average 73.7 billion cubic feet per day (Bcf/d) in 2017, a $1.4 \mathrm{Bcf} / \mathrm{d}$ increase from the 2016 level. Natural gas production in 2018 is forecast to be $4.4 \mathrm{Bcf} / \mathrm{d}$ higher than the 2017 level. In August (2017), the average Henry Hub natural gas spot price was $\$ 2.90$ per million British thermal units (MMBtu). Expected growth price rising from an annual average of $\$ 3.05 / \mathrm{MMBtu}$ in 2017 to $\$ 3.29 / \mathrm{MMBtu}$ in 2018. NYMEX contract values for December 2017 for about $\$ 4.34 / \mathrm{MMBtu}$ at the $95 \%$ confidence level. ${ }^{12}$

The rest of the world launched the search for gas and shale oil, although this search was contained by technological demand. For economically viable exploitation, a very large technological input is needed, and many countries with large reserves have neither the financial resources nor the human capital for economic exploitation

12 EIA - International Energy outlook 2017. Washington, DC. Retrieved from https://www.eia.gov/pressroom/ presentations/mead_91417.pdf on 18/18/2017. 


\begin{tabular}{|l|l|l|l|}
\hline Item & Country & $\begin{array}{l}\text { Estimate of recover- } \\
\text { able shale (2013) } \\
\text { (Trillion cubic feet) }\end{array}$ & $\begin{array}{l}\text { Proven } \\
(2013) \\
\text { (Trillion cubic feet) }\end{array}$ \\
\hline 1 & China & 1,115 & 124 \\
\hline 2 & Argentina & 802 & 12 \\
\hline 3 & Argélia & 707 & 159 \\
\hline 4 & Estados Unidos & 665 & 318 \\
\hline 5 & Canadá & 573 & 68 \\
\hline 6 & México & 545 & 17 \\
\hline 7 & África do Sul & 485 & - \\
\hline 8 & Austrália & 437 & 43 \\
\hline 9 & Rússia & 285 & 1,688 \\
\hline 10 & Brasil & 245 & 14 \\
\hline
\end{tabular}

Fonte: https://www.eia.gov/analysis/studies/worldshalegas/

Brazil has important reserves; however, exploitation has not been a priority for the government or companies, even multinationals. As the US has very large reserves, there should be no interest on the part of its companies to exploit shale in other countries.

However, the environmental problem persists. The United States has chosen to return to the 19th Century in energy production decisions for the 21st Century. An important difference that distinguishes these two moments in the history of humanity is that today there is a need to adopt clean sources of energy, renewable sources that cause less GHG emissions, since these emissions compromise the future life of humans on this planet.

At the beginning of his administration, President Trump showed the same disposition to return to the practices of the pre-industrial era. The distraction of the Paris Agreement and the statements that the United States, the world's second largest GHG emitter, is not concerned about emissions and that the government's main objective is the employment of its citizens and the will to make America great again, even on the path of uncontrolled emissions, reactivating the mines and the coal economy. This type of claim has no place in the 21 st Century, certainly, soon, this government will review these positions. 
The US economy is very dynamic and responds very quickly to good market opportunities. Another important point is that some products are considered strategic and receive subsidies and all kinds of support needed to be produced.

In the year 2000, the United States produced 6.2 billion liters of corn ethanol. The strategy of self-sufficient energy production led the country to produce 49.3 billion liters of corn ethanol in 2010. In 2011, the ethanol industry processed 128 million tons of maize, that is, much more than Brazil can produce in two years. EIA (2014)

The United States will produce 136 billion liters of ethanol, most of which will be added to gasoline to reduce GHG emissions. All this is related to the Law of Independence and Energy Security (EISA - Energy Independence and Security Act $)^{13}$, also called RFS2, which set the ethanol production target of 136 billion liters for the year 2022. What can be observed so far is that it does not matter what kind of fuel and whether it is sustainable or even viable. What matters to the greatest economic and military power of the planet is energy security. This is not absurd and even makes sense to its decision-makers, not to the other beings that inhabit the same planet.

\section{THE TRAP OF BRAZIL, POPULISM AND CRISIS}

In the 1970s and 1980s, the difficulties of obtaining fossil fuels, such as gasoline and diesel, to move the entire transportation system of the countries became more acute and led Brazil to become a major producer of ethanol, which has been consumed as fuel on a large scale in the country for more than 40 years.

It is important to note that ethanol is unviable when it exceeds $70 \%$ of the price of gasoline. On the other hand, when the price of sugar rises in the international market, industries that can choose to produce ethanol or sugar, decide to produce sugar, harming the supply of ethanol for use in vehicles

13 UNITED STATES. Congress. Energy Independence and Security Act of 2007 (EISA): H.R. 6. Washington, DC, 2007. Retrieved from: <http://www.energy.wsu.edu/ documents/library/EnergyAct2007Text.pdf>, on 12/05/11. 
During the period from 1975 to 2006, there were ups and downs of ethanol production and consumption in Brazil. These movements have always been dependent on the price of oil in the international market, which by its turn depended much more on political and strategic decisions than on market supply and demand.

Oil prices in the international market remained low until 2006, which made ethanol production unviable. As of this year, with the rise in oil prices, there was a resumption of ethanol production and the Brazilian automobile industry created the flex-fuel car, which consumes gasoline or ethanol, as the price of each one is more attractive. This also favored the installation of adequate infrastructure for the commercialization of hydrated ethanol, consumed directly from the ethanol pump at the fuel station.

There is also the commercialization of gasoline already mixed with up to $27 \%$ anhydrous ethanol. This economic and strategic growth for the Brazilian industry was interrupted from 2009, motivated by the crisis, but also by other important facts that will be shown here.

As of 2010 ethanol production in Brazil suffered economic impacts motivated by the production of shale gas in the US, which led its investments to move back also motivated by the increased production of corn ethanol, shown previously, to control part of its production and consumption of energy.

On the other hand, the government of President Roussef decided to control inflation artificially, aiming at her re-election. President Roussef determined that Petrobras would subsidize part of the price of gasoline consumed by the population, thus avoiding an increase in inflation.

The low price of gasoline means the unfeasibility of ethanol production, as has been said before. These acts committed by the Rousseff government harmed Petrobras that suffered a true attack of corruption, revealed in the operation Lava Jato, almost went bankrupt. 
The damming of inflation, which inevitably came later, and the sacrifice in ethanol production and industry, caused losses to ethanol producers of approximately U\$ 12 billion between 2011 and $2014 .{ }^{14}$

Without adequate remuneration, with high costs, and with the attractive price of sugar, many mills have opted to stop activities or produce only sugar, which has led Brazil to import ethanol for two consecutive years, since 2014.

Ethanol plants opted to delay tax payments; others delayed the renewal of sugarcane plantations, reducing the supply of sugarcane. For others, the alternative was long-term indebtedness, according to information from Brazil's agro-energy sector. By 2016, at least 80 units had been stopped or under judicial $\mathrm{re}^{15}$. The government of President Temer has rescued a program that had been thought of in sectors of academia and business associations, which is associating with the objectives of COP21, Paris Agreement. This program, called RenovaBios, proposes the improvement of policies and regulatory aspects of biofuels, to contribute to overcoming the technical and economic challenges to be faced by the sector that affect the biofuel market, according to the government itself and the business sectors.

Sustainability should not be questioned and is the most important goal to be pursued by society. The 1987 Brundtland Report, also known as "Our Common Future" in the UN World Commission on Environment and Development, defined sustainability. For this, it proposed that sustainability is based on three dimensions. The environmental dimension, the economic dimension, and the social dimension. The use of natural resources with the reduction of polluting waste, minimization of damage to ecosystems, use of recyclable materials, conservation of energy and use of clean technologies that, at the same time, contribute to the improvement of the living conditions of the population and decrease of social differences, with optimization of private or public resources, without compromising the ability of future generations to meet their own needs.

14 MACROSECTOR CONSULTORES. Retrieved from http://www.macrosector.com.br/congelar-preco-da-gasolinano-governo-dilma-custou-r-40-bi-a-usinas/ 2016, on 27/09/2017.

15 Conversion made by the author 


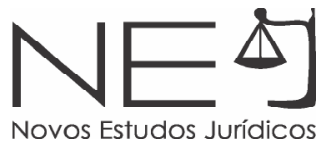

In recent times, the conferences have written the history of environmental negotiations with advances and setbacks. The 1972 Stockholm Conference focused on the environmental effects of energy production. The 1992Rio de Janeiro Conference sought to balance environmental and economic aspects of energy production and consumption. The 2002 Johannesburg Conference expanded the vision to consider beyond three dimensions and tried to balance the concept of the three by reinforcing the social aspects of sustainability. People and poverty eradication also become priorities and goals for UN negotiators.

Brazil is internationally recognized as a country that has achieved a high level of sustainability in its energy matrix, particularly in the transportation sector. For no other reason, Brazil has taken a leading role and leadership in the world forums on climate change.

The debate on the production of bio-energy versus food production stems mainly from the occupation of land. Another point that can be added in this discussion is the replacement of fossil fuels.

The main Brazilian biofuels are ethanol and bio-diesel, and they use raw materials that produce, alternatively, food and renewable energy. Sugarcane produces sugar, ethanol, and bio-electricity. Soybean, in turn, produces biodiesel and produces protein for animal and human food, which is the bran and, as a co-product, the oil, for food consumption and for the production of biodiesel, which depends on oil prices to be economically viable.

The Paris Agreement, presented at the 21st Conference of the Parties COP21 in December 2015, led Brazil to commit itself to carbon reductions of 37\% by 2025 , and of $43 \%$ by 2030 , both based on 2005 levels.

Among the commitments made in energy production and consumption, up to 2030, the following should be highlighted: increasing bio-energy participation in the energy matrix to approximately $18 \%$, expanding the consumption of biofuels and achieving a $45 \%$ share of renewable energy in the composition of the energy matrix. 
In the early 2000s, Latin America and Brazil leaped to the left. 15 countries were governed by members of the Forum of Sao Paulo, who declared their option for socialism and radical nationalism. Excerpts from Lula's letter to the Brazilian people on 22/06/2002 show the essence of populism that has marked the last 20 years, since Hugo Chávez's victory in Venezuela.

Our people note with regret and indignation that the economy has not grown and is much more vulnerable, the country's sovereignty has been largely compromised, corruption remains high and, above all, the social crisis and insecurity have become frightening

The road to tax reform, which reduces the cost of production. Land reform to ensure peace in the countryside. Reducing our energy shortages and our housing deficit. Social security reform, labor reform, and priority programs against hunger and public insecurity.

The predominant feeling in all classes and all regions is that the current model has run out. Therefore, the country can not insist on this path, under penalty of being in a chronic stagnation or even of suffering, sooner or later, an economic, social and moral collapse.

Founded in 1990 by Lula and Fidel Castro - according to Lula's idea, he declared in May 2011. The "São Paulo Forum is the largest political organization that has ever existed in Latin America and certainly one of the largest in the world. It is attended by all the leftist leaders of the continent. But it is not a leftist organization like any other. It brings together more than one hundred legal parties and several criminal organizations linked to drug trafficking and the kidnapping industry, such as the FARC and the Chilean MIR, all of them committed to a common strategic articulation and seeking mutual advantages. It has never been seen in the world, on such a gigantic scale, such an intimate, persistent, so organized and enduring coexistence between politics and crime.

It cannot be said for sure what are the reasons and causes for the overthrow of these regimes and that organization. What can be said, by simple observation, is that it has been disrupted year after year. Their leaders have been denounced, killed, arrested or charged awaiting a court decision. 


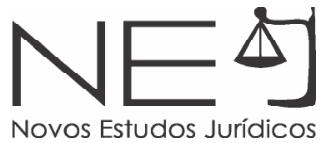

HOW WILL THE PLANET REACH 2050?

The world population had 7.3 billion people in 2017 and will reach 8.5 billion by 2030 and 9.7 billion by 2050, according to the UN, 2015.

World population growth has several impacts on resources and social services such as education, health, transportation, food. FAO has specifically warned about changes in climate and the consequent reduction in food production, as well as an increase in the incidence of diseases, among other consequences.

Climate change has both direct and indirect effects on agricultural productivity, including changing rainfall patterns, drought, flooding and the geographical redistribution of pests and diseases. The vast amounts of $\mathrm{CO} 2$ absorbed by the oceans cause acidification, influencing the health of our oceans and those whose livelihoods and nutrition depend on them. FAO, retrieved from http://www.fao.org/climatechange/en/.

Scholars from Embrapa, a Brazilian agricultural research company have been concerned with raising the global average temperature by $2^{\circ} \mathrm{C}$ and alerted to the need for Brazil to have its research adapted to its climatic reality.

According to the IPCC (2016), in 1960 the level of CO2 concentration in the atmosphere was 574 gigatons, in 2014 it increased to 2,000, and it is predicted that if nothing changes in emissions by 2030, the planet can reach 3,200 gigatons, enough to trigger a process of global warming in $2^{\circ} \mathrm{C}$, which would take thousands of years to return to the previous situation.

This temperature increase changes fundamental biological processes for the survival of humans, the growth of plants and the reproduction of animals.

According to EIA, world energy consumption increases from 575 quadrillion Btu in 2015 to 736 quadrillion Btu in 2040, a 28\% increase. The world population increase and the increase in energy consumption occur in more or less the same proportion. At least the same proportion of energy resources and raw materials to produce food, clothing, transport, educational products, and services. 
Traditionally, the increase in energy consumption has been in developed countries because they have economies that are more demanding of resources in general, and especially energy. In the coming decades, there will be an important change to this tradition. What is predicted now is that more than $60 \%$ of the increase in consumption will occur in emerging countries such as Brazil, China, India, South Africa, Indonesia, and Mexico. By the year 2040, these countries will consume a lot of energy in the transportation and residential sectors, yet the industrial processing sector will still account for more than $50 \%$ of energy consumption. Energy consumption related to the transport of goods and people will increase by around 30\% in non-OECD countries. This means that developed economies have reached a certain maturity in terms of the need for transportation fuels. Therefore, the emerging economies mentioned above will continue to increase energy consumption for transportation.

Between the years 2015 and 2040, the consumption of renewable energy will be $2.3 \%$ per year. The UN agreements will continue to motivate countries to transform their energy matrix by prioritizing renewable energy. However, by 2040, fossil fuels will still dominate energy consumption. The EIA estimates that world consumption this year will require $77 \%$ of fossil origin. Consumption of natural gas will grow at an average of $1.4 \%$ per year in the 25 years between 2015 and 2040. While coal will experience significant growth. Despite a reasonable reduction planned for Chinese consumption, there will be a significant increase in India and other parts of Asia and thus there will be the maintenance in the level of regional consumption.

\section{BIO-ECONOMICS, THE PROMISE AND THE FUTURE}

In the last decades, a different way of cooperation has appeared that can be observed in new sciences grouped around the bio-economy. This grouping synthesizes the search for something that interests all beings that inhabit the planet, respecting diversity and projecting the future in a cooperative and shared way.

The new world of the 21st Century begins to design industries different from those created and used after the industrial revolution, which were used 


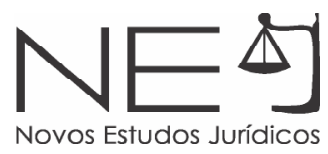

for at least 130 years, during the period from the end of the 19th century to the beginning of the 21st century. Considering warnings from scientists, it is unreasonable to continue with the volume of greenhouse gas emissions or with products that generate waste that is difficult to degrade and reuse. It is not yet known with certainty what will come soon, but some clues can be laid: products must be at least biodegradable, intensive in technology, providing great increases of productivity, with reduced energy consumption. Technologies need to be based on genetic engineering, bioinformatics, nanotechnology, and artificial intelligence and metadata. This is the most important social demand, both now and in the near future.

Over the past two decades, biotechnology has provided a motor for environmentally sustainable production and the development of a diverse range of innovative products. The continued commercial application of biotechnology could lead to the development of a bio-economy, where a substantial share of economic output is partly dependent on the development and use of biological materials. ${ }^{16}$

The use of biological resources economically is not new; however, the intensive and combined use of genetic engineering, biotechnology, metadata, nanotechnology, and even aerospace science have led to paradigmatic changes in the way of production and the goods and services produced. For example, the use of algae, fungi, and bacteria to produce goods, as it has been used, is something entirely new. This can be generated from biodegradable plastics to super drugs.

According to the OECD, there are three main sectors where biotechnology can be applied: agriculture, health, and industry. While primary production includes all living natural resources such as forests, plants, animals, insects, fish, and other marine resources, the main current uses of biotechnology are for the creation and diagnosis of plants and animals. Human health applications include therapeutics, diagnosis, pharmacogenetics to improve prescribing practices, functional foods and nutraceuticals, and some medical devices.

16 OECD. The Bioeconomy to 2030: Designing a Policy Agenda. Retrieved from www.oecd.org/futures/ bioeconomy/2030, on 08/2017. 
Industrial applications include the use of biotechnological processes to produce chemicals, plastics, and enzymes, environmental applications such as bioremediation for cleaning polluted soils, bio-sensors, methods to reduce the environmental effects or costs of resource extraction and the production of biofuels. Various applications, such as bio-pharmaceuticals, in vitro diagnostics, some types of genetically modified crops and enzymes are comparatively "mature" technologies. Many other applications have limited commercial viability without supporting policies (e.g., bio-fuels and bio-plastics) or are still in the experimental phase, such as regenerative medicine and RNA interferencebased health therapies.

Many industrial segments are involved in generating new jobs for new and old professions. Sustainable products and services have demanded initiatives and discussions about the establishment of something called bio-law. Rules to organize all these news need to be very fast and technologically updated. Much of Bio-ethics needs to be discussed to arrive at conclusions on which processes can be considered and which cannot.

In March 2017, the National Academy of Sciences in Washington, DC, approved the use of Crisp technology to edit the human genome and for the first time, an experiment was done that altered the genome of humans. The results were published in the journal Nature on 8/1/2017 and had already been published in the MIT Technology Review. By 2015 Chinese scientists had done something similar by modifying human genomes.

The right to modify DNA structures resulting in less pollution and impact on climate change; the right to cooperate by exchanging technologies and supplying food and improving the health of the human population on earth, which continues to grow and demand food, medicine, clothes, transport, everything that the economy can offer, begins to be considered by the scientific society and even by the parliaments of several countries, such as the USA and France.

On the other hand, it is possible to observe in the industrialized economies certain exhaustion of the model implanted in the late nineteenth century. 
Ecological depletion when it comes to sustainability and depletion of productivity when it comes to new and revolutionary technologies. The externalities of typical twentieth-century capitalism are bothering critics and observers who are responsible and committed to future generations and even to the survival of the human being on this planet. The need to expand the supply of food, health, energy and clean water as well as mitigation of climate change is an example of how this new form of production can be useful and save many lives of humans and animals in the coming years. Global energy-related carbon dioxide emissions are projected to grow by an average of 0.6\% per year between 2015 and 2040. This consumption ratio will be lower than the $1.3 \%$ in the 1990 to 2015 period.

\section{THEORY OF SOCIAL MUTATIONS AS AN EPILOGUE}

About 70,000 years ago, organisms belonging to the species Homo sapiens began to create even more elaborate structures called cultures. The subsequent development of these human cultures is called history. Three major revolutions have defined the course of history. The Cognitive Revolution began the story about 70,000 years ago. The Agricultural Revolution accelerated it, around 12,000 years ago, and the Scientific Revolution, which began only 500 years ago. ${ }^{17}$

According to Harari ${ }^{18}$, Cooperation sounds very altruistic, but it is not always voluntary and rarely equal. Most human cooperation networks are designed for oppression and exploitation. At some point in their existence, the Sapiens began to tell stories and convince others that these stories were important and true. Since then, human beings cooperate when they agree with the same story, that is, everyone admits that such a story is true, feel happy to adopt it, or at least, it makes sense to them. These stories are everywhere, they are part of the education that we Sapiens give our children and that they transmit to our grandchildren.

Stories about identities of origin, about beliefs or religions, about how the world was created, about life after death, about resurrection, about the importance of money and wealth, about the model of children's education,

17 Harari, Yuval Noah. Homo Deus: Uma breve história do amanhã (Locais do Kindle 7089-7090). Companhia das Letras. Edição do Kindle. RAJAGOPAL, D.; SEXTON, S.; HOCHMAN, G.; ZILBERMAN, D. Recent Developments in Renewable Technologies: R\&D Investment in Advanced Biofuels. Annual Review of Resource Economics, Palo Alto, v. 1, p. 621-644, 2009.

18 Harari, Yuval Noah. Homo Deus: Uma breve história do amanhã. p. 32-35. 
Novos Estudos Jurídicos

about international corporations, about the states, about almost everything that organizes the society of each country and about the international society, the latter being a more recent fact. ${ }^{19}$

All conflicts, from great wars to small conflicts between football fans, can be explained by this understanding. It has been at least since the Cognitive Revolution, between 70 and 30 thousand years ago, when the Sapiens became, it is not known how, in beings that manage to cooperate flexibly, in large groups and for this they dominated the planet. And then the Sapiens who were fragile beings with no biological or sociological instruments to face their competitors in the early days of their life in East Africa. ${ }^{20}$ Cooperating means that everyone must agree with the stories that have been told or proposed by some and that can not suffer any opposition. For this to work, it is important to persuade more and more people to follow and legitimize the story adopted socially.

The agricultural revolution invented the work and some Sapiens created stories that convinced many to work weeding the fields, fighting the plagues, irrigating and dealing with livestock. Then, with the agricultural revolution, a smarter small group stood out that went on to use tradition and the law that preached that many should work to promote the security, in the general sense, of the leaders. They were princes, clergy, and military chiefs who became politically strong when the first villages were formed, grew as cities emerged and took on even greater proportions when the empires took shape. This can be called flexible and large-scale cooperation. The result was very bad for the individual people, however, very good for the Sapiens as a species, which multiplied and became very powerful, threatening all other species, even the largest predators.

Stories that denied one's beliefs should be banned. Stories that jeopardized one's truthfulness were not welcome because they made one and his/her believers go through difficulties believing something that is not true. They could destabilize the entire social system, so they were a great threat and should be fought with all available means. This is the best explanation of conflicts and wars. $^{21}$

19 HARARI, Yuval Noah. Homo Deus: Uma breve história do amanhã. São Paulo: Companhia das Letras, 2015.

20 HARARI, Yuval Noah. Homo Deus: Uma breve história do amanhã. São Paulo: Companhia das Letras, 2015.

21 HARARI, Yuval Noah. Homo Deus: Uma breve história do amanhã. São Paulo: Companhia das Letras, 2015. 
Huntington, in his work Clash of Civilizations, explains that conflicts occur much more by cultural differences than by any other reason. The most important critiques to Huntington's work are more tied to the way he divided civilizations than to cultural shocks. It is important to note that there may be conflicts for reasons that are not necessarily between different stories. And this does not invalidate the theory that the stories that establish beliefs are the major reasons for cooperation, and the divergence between adherents of different histories is the main source of conflict. Dawkins, in The Selfish Gene, introduces the concept of meme that can be explained as being a kind of social gene. Genes need to survive and reproduce and any obstacles must be overcome to achieve these vital goals.

Likewise, memes have to be replicated and must survive to perpetuate themselves, and here they are confused with Harari's concept of the missionary activity of persuading others to believe in one's beliefs, a typical case of monotheistic religions, in which one's belief is the only true. Otherwise, infidels must be eliminated because they threaten one's sacred beliefs.

Just as genes propagate on the "bottom" jumping from body to body through sperm or female eggs, so do memes propagate in the "bottom" of memes jumping from brain to brain by a process that can be called, in the broad sense, imitation. ${ }^{22}$ When you plant a fertile meme in my mind, you literally parasite my brain, transforming it into a vehicle for the propagation of the meme, just as a virus can parasite the genetic mechanism of a host cell. And this is not just a way of speaking - the meme, for example, for "belief in an afterlife" is physically realized, millions of times, as a structure in the nervous systems of men individually for all the world. ${ }^{23}$ The survival value of the meme to God on the "bottom" results from his great psychological attraction. It provides a superficially plausible answer to deeply disturbing questions about existence. He suggests that injustices in this world may be corrected in the next. ${ }^{24}$

A meme with great power of survival and reproduction is God. It is not known how the idea of God originated, perhaps of independent mutations. In any case, it is very old and is replicated by the written and spoken word, aided by

22 DAWKINS, Richard. The Blind Watchmaker. New York: Norton, 1986, p. 180.

23 HUMPHREY, Nicholas K. Consciousness Regained: Chapters in the Development of Mind, Oxford University Press, 1983.

24 DAWKINS, Richard. The Blind Watchmaker. New York: Norton, 1986, p. 188. 
Novos Estudos Jurídicos

music, poetry and all forms of art. She is always exploring the greatest fears and the most important hopes, desires, and dreams.

In the first decades of the XXI Century, there is the appearance of new stories, called global religions, by Harari. For example, the responsibility of all humans for the preservation of the planet. Global religions are a new fact in the history of mankind, they arise from the very expansion of communication and the publicity of the global demands of scientists and the marketing calls of environmentalists and their non-governmental organizations. Its embryos are global human rights, global environmental rights, animal rights, intellectual property rights, legal security in all countries for investors.

Dataism is also a powerful new religion because it tells everyone that we should believe in algorithms more than in ourselves or in our feelings that have been forged for more than 4 million years. According to Harari, we evolved from belief in God (deism) to believe in ourselves (humanism) to belief in data (dataism).

\section{REFERENCES}

ANDREOLI, C.; SOUZA, S. P. de. Cana-de-açúcar: a melhor alternativa para conversão da energia solar e fóssil em etanol: texto para discussão. Economia \& Energia, ano X, n. 59, p. 27-33, 2006.

ALMEIDA, Wilson J. B . Ethanol Diplomacy: Brazil and U.S. in Search of Renewable Energy. Revista de Globalizacion, Competitividad y Gobernabilidad, v. 3, p. 114-124, 2009.

BLOOMBERG (2017). Retrieved from https://www.bloomberg.com/research/stocks/private/ snapshot.asp? privcapld=33230078 on September 2017.

CONAB. Companhia Nacional de Abastecimento. Acompanhamento da safra brasileira: canade-açúcar: safra 2010/2011: segundo levantamento. 2010. Retrieved from: http://www.conab. gov.br on March. 2011.

DAWKINS, Richard. The Blind Watchmaker. New York: Norton, 1986.

EIA - International Energy outlook 2017. Washington, DC. Retrieved from https://www.eia. gov/pressroom/presentations/mead_91417.pdf on 18/18/2017.

EIA - International Energy Outloock 2017. Retrieved from https://www.eia.gov/outlooks/ steo/ on 17/09/2017. 


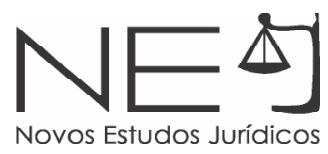

EIA - World Shale Resource Assessments. Retrieved from https://www.eia.gov/analysis/ studies/worldshalegas on 03/10/2017.

EMBRAPA. Nova era genômica e a biodiversidade brasileira, nota técnica $n^{\circ} 6.2012$. Retrieved from https://www.embrapa.br/en/busca-de-publicacoes/-/publicacao/927143/a-nova-eragenomica-e-a-biodiversidade-brasileira on 29/08/2017.

FOOD AND AGRICULTURAL POLICY RESEARCH INSTITUTE. FAPRI 2010: U.S. and world agricultural outlook. Ames: lowa State University; University of Missouri, 2010. 418 p. (FAPRI Staff Report, 10-FSR). Retrieved from http://www.fapri.org/outlook/2010/text/OOtlook_2010. pdf on Apr 2011.

GEHLHAR, M.; WINSTON, A.; SOMWARU, A. Effects of increased biofuels on the U.S. Economy in 2022. Washington, DC: Usda-Economic Research Service, 2010. 36 p. (Economic Research Report, 102). Retrieved from: http://www.ers.usda.gov/Publications/ERR102/ ERR102.pdf on May 2011.

GOLDEMBERG, J. The case renewable energy. In: INTERNATIONAL CONFERENCE FOR RENEWABLE ENERGIES, 2004, Bonn. Proceedings... Bonn: Secretariat of the International Conference for Renewable Energies, 2004. Retrieved from <http:// www.renewablesbonn-2004.de/pdf/tbp/TBP01- rationale.pdf> on May 2010.

HARARI, Yuval Noah. Homo Deus: Uma breve história do amanhã. São Paulo: Companhia das Letras, 2015.

INPE. Retrieved from http://www.inpe.br/acessoainformacao/node/483SEATTLE on Sep 2017. LUCON, O.; GOLDEMBERG, J. Crise financeira, energia e sustentabilidade no Brasil. Estudos Avançados, v. 23, n. 65, p. 121-130, 2009.

MACROSECTOR CONSULTORES. Retrieved from http://www.macrosector.com.br/congelarpreco-da-gasolina-no-governo-dilma-custou-r-40-bi-a-usinas/ 2016 on 27/09/2017.

MENDONÇA, M. A. Expansão da produção de álcool combustível no Brasil: uma análise baseada nas curvas de aprendizagem. In: CONGRESSO DA SOCIEDADE BRASILEIRA DE ECONOMIA, ADMINISTRAÇÃO E SOCIOLOGIA RURAL, 46., 2008, Rio de Branco. Anais. Rio Branco: BNDES, 2008.

MICHELLON, E.; SANTOS, A. A. L.; RODRIGUES, J. R. A. Breve descrição do Proálcool e perspectivas futuras para o etanol produzido no Brasil. In: CONGRESSO

DA SOCIEDADE BRASILEIRA DE ECONOMIA, ADMINISTRAÇÃO E SOCIOLOGIA RURAL, 46. 2008, Rio Branco. Anais... Rio Branco: BNDES, 2008.

MOLINARI, P. Tendências grãos 2001/12. 2009. Retrieved from: www.ocepar.org.br on Apr 2011. 
NATIONAL ECONOMIC COUNCIL. A strategy for american innovation: driving towards sustainable growth and quality jobs. 2009. Retrieved from: http://www.whitehouse.gov/ administration/eop/nec/ StrategyforAmericanlnnovation/ on Oct. 2010.

New York Times, edition 02/02/2009

Living Planet Report 2014, WWF Global Retrieved from < http:// wwf.panda.org/ about_our_ earth/ all_publications/ living_planet_report/ > on Sep 2017.

Harari, Yuval Noah. Homo Deus: Uma breve história do amanhã (Locais do Kindle 70897090). Companhia das Letras. E-book.

RAJAGOPAL, D.; SEXTON, S.; HOCHMAN, G.; ZILBERMAN, D. Recent Developments in Renewable Technologies: R\&D Investment in Advanced Biofuels. Annual Review of Resource Economics, Palo Alto, v. 1, p. 621-644, 2009.

HUMPHREY, Nicholas K. Consciousness Regained: Chapters in the Development of Mind, Oxford University Press, 1983.

OBAMA, Barak. Discurso no Fórum Cidadão Global. Valor Econômico, Retrieved from http:// www.valor.com.br//brasil/5147036/leia-integra-da-palestra-de-barack-obama-no-forumcidadao-global on 06/10/2017.

OECD. The Bioeconomy to 2030: Designing a Policy Agenda. Retrieved from www.oecd.org/ futures/bioeconomy/2030 on Aug 2010.

Organização das Nações Unidas (ONU)."Perspectivas da População Mundial: A Revisão de 2015", Jul/2015.

RENEWABLE FUELS ASSOCIATION. Building bridges to a more sustainable future. Washington, DC: RFA, 2011. 38 p. (2011 Ethanol Industry Outlook). Retrieved from http://www.ethanolrfa. org/page/-/2011\%20RFA\%20 Ethanol\%20Industry\%200utlook.pdf?nocdn=1 on March 2011.

RENEWABLE FUELS ASSOCIATION. Climate of opportunity. Washington, DC: RFA, 2010. 36 p. (2010 Ethanol Industry Outlook).

SHELDON, I.; ROBERTS, M. U.S. comparative advantage in bioenergy: a Heckscher-OhlinRicardian approach. American Journal of Agricultural Economics, Lexington, v. 90, n. 5, p. 1233-1238, 2008

SUZIGAN, W.; FURTADO, J. Política industrial e desenvolvimento. Revista de Economia Política, São Paulo, v. 26, n. 2, p. 163-185, 2006.

STATE DEPARTMENT. Advancing Cooperation with Brazil on Biofuels. 2006. Retrieved from https://2001-2009.state.gov/r/pa/prs/ps/2007/mar/81589.htm. on 27/09/2017. 
SEATTLE TIMES. Retrieved from http://www.seattletimes.com/nation-world/bush-talks-upethanol-in-brazil/ on 18/09/2017

TYNER, W. E. Policy alternatives for the future biofuels industry. Journal of Agricultural \& Food Industrial Organization, Berkeley, v. 5, n. 2, p. 1-11, 2007.

UNITED STATES. Congress. Energy Independence and Security Act of 2007 (EISA): H.R. 6. Washington, DC, 2007. Retrieved from http://www.energy.wsu.edu/ documents/library/ EnergyAct2007Text.pdf on May 2011.

UNITED STATES. Department of Agriculture. Grain: world markets and trade. Washington, DC: USDA-Foreign Agricultural Service, 2010. 56 p. (Circular Series, FG 08-10). Retrieved from http://www.fas.usda.gov/grain/ circular/2010/08-10/grainfull08-10.pdf on March 2011.

UNITED STATES. Department of Agriculture. USDA Agricultural Projections to 2018. 2009. Retrieved from http://ers.usda.gov/Publications/OCE091/OCE091.pdf on Apr 2011.

URBANCHUK, J. M. Contribution of the ethanol industry to the economy of the United States. 2006. Retrieved from http://www.ethanolrfa.org/page/-/objects/ documents/576/economic_ contribution_2006.pdf on Oct 2010.

World Bank Data. Retrieved from www.worldbank.org. on Sep 2017.

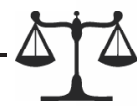

